Sains Malaysiana 50(7)(2021): 1885-1899

http://doi.org/10.17576/jsm-2021-5007-05

\title{
Fluvial-Tidal to Fluvial-Lacustrine Sedimentation of the Middle Miocene to Pleistocene Mapia Formation, Dogiyai, Papua (Indonesia)
}

(Pengendapan Fluvium-Pasang Surut hingga Fluvium- Lakustrin daripada Penghasilan Mapia Miosen Tengah hingga Pleistosen, Dogiyai, Papua (Indonesia))

\author{
RAKHMAT FAKHRUDDIN*
}

\section{ABSTRACT}

A sedimentological and palynological investigation was carried out on outcropping sedimentary rocks at Dogiyai, Papua, proposed to be named as the Mapia Formation. The age range is from Middle Miocene to Pleistocene. The lower Mapia Formation was deposited at Metroxylon type to Nothofagus emarcida Zone, Middle Miocene to Early Pliocene. It is comprised of three facies associations: tidal channel, tidal point bar, and tidal flat deposits. A tidally dominated fluvially influenced depositional environment is suggested for the deposition of sediments of this unit. The upper Mapia Formation was deposited at Malvacipollis diversus Zone, Garcinia cuspidata type Zone, and Proteacidites sp. Zone, Late Pliocene to Pleistocene. It is comprised of five facies associations: delta front, slump, debrite, turbidite, and lacustrine mud deposits. A non-channelized deep-lacustrine slump and debris-flow dominated depositional environment is suggested for the deposition of sediments of this unit. The lower Mapia Formation was deposited as synorogenic clastic sediments at the beginning of Central Range orogeny event while the upper Mapia Formation was deposited in the piggyback basin at the major uplift event.

Keywords: Central Range orogeny; Indonesia; Mapia formation; Middle Miocene-Pleistocene; Papua

\section{ABSTRAK}

Penyelidikan sedimentologi dan palinologi dilakukan terhadap singkapan batuan sedimen di Dogiyai, Papua, yang diusulkan untuk disebut sebagai Penghasilan Mapia. Julat umur adalah daripada Miosen Tengah hingga Pleistosen. Penghasilan Mapia yang lebih rendah disimpan pada jenis Metroxylon ke Zon Nothofagus emarcida, Miosen Tengah hingga Pliosen Awal. Ia terdiri daripada tiga kumpulan fasies: saluran pasang surut, bar titik pasang surut dan deposit rata pasang surut. Persekitaran penyimpanan yang fluvium terpengaruh pasang surut terdominan disarankan untuk penyimpanan endapan unit ini. Penghasilan Mapia atas disimpan di Zon Malvacipollis diversus, Zon jenis Garcinia cuspidata, dan Zon Proteacidites sp., Akhir Pliosen hingga Pleistosen. Ia terdiri daripada lima kumpulan fasies: permukaan delta, nendat, debrit, turbidit, dan penyimpan lumpur lakustrin. Persekitaran pemendapan nendat lakustrin dalam yang tak disalur dan aliran puing yang terdominan adalah dicadangkan untuk penyimpanan endapan unit ini. Penghasilan Mapia yang lebih rendah disimpan sebagai endapan klastik sinorogenik pada awal kejadian orogeni Julat Pusat sementara Formasi Mapia atas disimpan di lembangan gendong pada kejadian peningkatan besar.

Kata kunci: Formasi Mapia; Indonesia; Miosen-Pleistocene tengah; orogeni Julat Pusat; Papua

\section{INTRODUCTION}

Sedimentological and palynological investigation has been undertaken of a Middle Miocene to Pleistocene sediment succession in the western part of Akimeugah Basin, Dogiyai regency, Papua province, Indonesia. The sections are outcropping at a recently cut road resulted by intensive road infrastructure built around the studied area (Figure 1). Previously, the section was included in Permian Aiduna Formation (geological map of Enarotali and Wagethe sheets) (Harahap et al. 1990; Panggabean \& Pigram 1989). 
The Middle Miocene to Pleistocene age in Papua area is represented by siliciclastic sedimentation on top of the Australian continental basement, which started after the cessation of carbonate shelf sedimentation and concurred with the Central Range orogeny event, which began in the latest Middle Miocene (van Ufford \& Cloos 2005). However, there is still limited publications regarding sedimentological and palynological work for the Middle Miocene to Pleistocene unit in Papua, Indonesia.

This paper aims to describe and interpret the facies association and biostratigraphy of the studied sections. Furthermore, this information is used to discuss the relation of stratigraphic succession with the tectonic history of Papua from previous workers. The results of this work are expected to provide some preliminary information to researchers engaged in researching Cenozoic palaeogeographic and tectonics reconstructions of Papua island.

\section{GEOLOGICAL SETTING}

The geological evolution of the rocks in the studied area is divided into Cambrian to Devonian pre-rift phase, Carboniferous to Jurassic syn-rift phase, Mesozoic post-rift passive margin, Tertiary passive margin (carbonate platform), Upper Oligocene to Middle Miocene convergence phase, and Upper Miocene to present Melanesian orogeny (Harahap 2012). In the study area, the Cambrian to Devonian pre-rift phase is represented by Silurian-Devonian Modio Dolomite (Panggabean \& Pigram 1989). Carboniferous to Jurassic syn-rift phase resulted in the deposition of Permian Aiduna Formation in fluvial to a mostly marginal marine environment and deposition of Triassic Tipuma Formation in the fluvial setting. Palynological analysis from samples of Aiduna Formation in Uteraupuko River $(35 \mathrm{~km}$ southeast of the studied area) gave an age of late Early to early Middle Permian (Playford \& Rigby 2008). It indicated a non-marine depositional environment for the sampled strata. The Kembelangan Group, which is mostly marine siliciclastic rocks, was deposited during the Mesozoic post-rift passive margin phase (Harahap 2012; Panggabean \& Pigram 1989).

The Paleocene to Eocene platform carbonate in the study area includes the lower Yawee Limestone/ Waripi Formation (Panggabean \& Pigram 1989). The Sirga Formation overlay with disconformity the Waripi Formation, known as Oligocene unconformity, which resulted from sea-level fall (Harahap 2012; van Ufford \& Cloos 2005). The Australian Plate began to collide with the Pacific Plate in the Late Oligocene time (Baillie et al. 2004; Harahap 2012; Hill \& Hall 2003; Hutchison 1989; Longley 1997; Pigram \& Panggabean 1984). The collision event led to regional metamorphism of the Mesozoic and lower Tertiary sediments called Derewo Metamorphic (Harahap et al. 1990; Harahap 1997; Warren \& Cloos 2007). A time of magmatic arc in Miocene-Pliocene represented by Utawa Diorite and Timepa Monzonite (Harahap et al. 1990; Panggabean \& Pigram 1989).

The deposition of limestone (upper Yawee Limestone) continued from Oligocene to Middle Miocene, until around 12 Ma (Panggabean \& Pigram 1989; van Ufford \& Cloos 2005). Melanesian orogeny/Central Range orogeny began in the latest Middle Miocene accompanied by shedding material of the fold-belts and deposition of the material to the south of Central Range (Harahap 2012; van Ufford \& Cloos 2005). The siliciclastic-rich landmass deposit, elongated east-west, extends more than $500 \mathrm{~km}$ known as the Klasaman, Akimeugah, Iwur, and lower Buru formations (Atmawinata et al. 1989; Harahap et al. 1990; Panggabean \& Pigram 1989; van Ufford \& Cloos 2005). In the Pliocene to Pleistocene, the mainland area was exposed above sea level which mark a sedimentological change where terrigenous detritus deposition took place, accumulated as molasse type deposits with a marine influence in part, known as the Sele, Steenkool, Dakebo, upper Buru and Birim formations (Atmawinata et al. 1989; Harahap et al. 1990; Panggabean \& Pigram 1989; van Ufford \& Cloos 2005).

\section{MATERIALS AND METHODS}

This study documents facies analysis of two composite stratigraphic sections exposed at the road cut along the road from Mapia to Modio and Mapia to Moanemani (Figure 1), named as the Mapia and Moanemani section (Figures $2 \& 3$ ). At the Mapia section, the unit targeted in this outcrop study is bounded at the base by the SilurianDevonian Modio Dolomite. The measured sections on the targeted unit record grain sizes, color, textures, bed thicknesses, sedimentary structures, bed contacts, and stratigraphic relationships (Chung et al. 2015; Hassan et al. 2013; Roslan et al. 2016). A combination of GPS waypoints with an average of dip measurements was used to calculate the thickness of non-exposure rocks in the sections. Facies analysis involved facies associations, groups of facies genetically related to one another, and which have some environmental significance, as subenvironments within a depositional system (Collinson 1969; Walker 2006). Classification based on similarity of 
sedimentary features for fluvial-tidal facies associations follows combination of Hughes (2012), Musial et al. (2013, 2012), Olariu et al. (2015), and Santos and Rossetti (2006), and for fluvial-lacustrine facies associations follows combination of Liu et al. (2017a), Olariu and Bhattacharya (2006), Shanmugam (2018), and Zou et al. (2012).

Palynological samples were collected from specific carbonaceous or coaly beds. Palynological analysis for
22 samples was performed in GeolLabs, Pusat Survei Geologi, Bandung, Indonesia. Fifty-gram weight per sample was extracted using $\mathrm{HF}$ and $\mathrm{HCl}$ and separated from the substrate using a zinc chloride solution. Sieving with a five $\mu \mathrm{m}$ mesh for the residue was carried out to separate palynomorphs from debris materials. The residue was then mounted on slides with glycerin jelly, and two slides per sample observed using 1000X magnification light microscope.
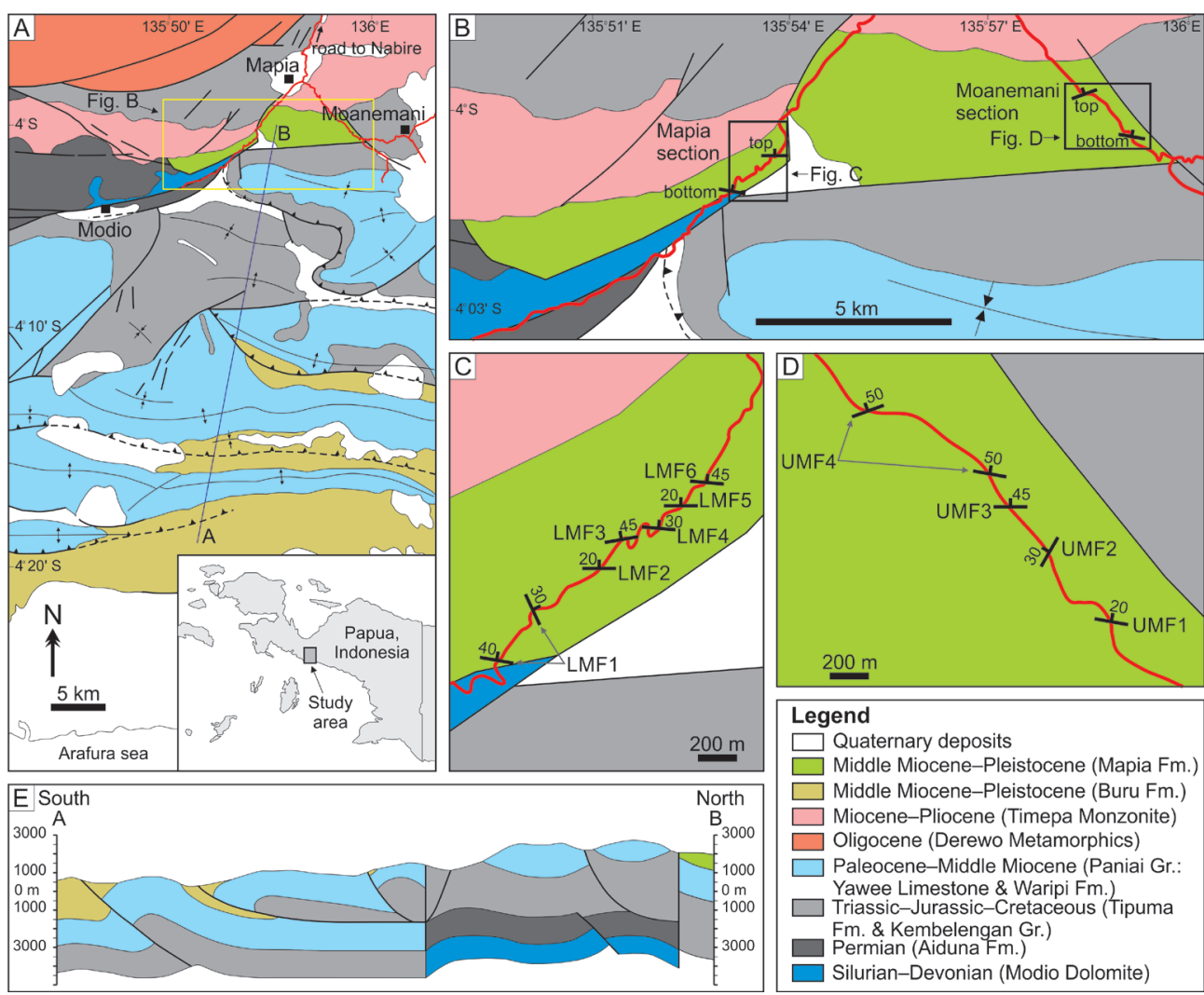

FIGURE 1. Location map of the study area. (A) Geological map of the Wagethe and Enarotali sheets (modified from Panggabean and Pigram (1989) and Harahap et al. (1990)). Yellow box showing the position of the study area, (B) Position of outcrop measured sections, Mapia and Moenamani sections. Close-up of the Mapia section (C) and the Moenamani section (D), and (E)

North-south geological profile of the study area showing the studied unit in the north

\section{RESULTS AND DiSCUSSION}

\section{FACIES ASSOCIATION}

Based on the similarity of sedimentary features, eight facies associations (FA) are identified in the studied unit
(Figures $2 \& 3$ ). Three FA (FA 1-FA 3) are included in the fluvial-tidal depositional environment, and five FA (FA 4-FA 8) are included in the fluvial-lacustrine depositional environment. The fluvial-tidal unit is found in the lower part of the Mapia section, and the fluvial-lacustrine 
unit is found in the upper part of the Mapia section and Moanemani section.

\section{FACIES ASSOCIATION 1 (FA 1): TIDAL CHANNEL DEPOSITS}

Description: FA 1 primarily consists of trough crossstratified very fine- to fine-grained sandstone, moderatelyto well-sorted, with irregular concave-up erosional based and subordinate intra-formational mud clast breccia (Figure 4(A) \& 4(B)). The cross sets are up to $60 \mathrm{~cm}$ thick that are separated by reactivation surfaces with some foresets draped by mudstone laminae. Uncommon ripple lamination also occurs. The breccia is composed of poorly-sorted, pebble to large boulder (up to $50 \mathrm{~cm}$ ), angular to subangular red mud clasts, and is found above erosive surface of FA 1 . The internal laminae of large boulder clasts show highly deformed laminae. This facies association is up to $6 \mathrm{~m}$ thick.

Interpretation: Trough cross-stratified sands were formed by the migration of 3D-bedforms within channels (Allen 1963). The concave upward erosional bounding surface at the base of this FA suggests confined flows within the channel (Santos \& Rossetti 2006). The intraformational breccia is representing lags deposit at the channel bottom from bank slumping and channel edge erosion due to lateral migration of the tidal channels (Hughes 2012). Furthermore, the reddish color mud clasts are interpreted to be derived from local reworking of the adjacent oxidized tidal flat deposit. The highly deformed laminae in the large boulder clasts indicate a slump origin (Hubbard et al. 2011).
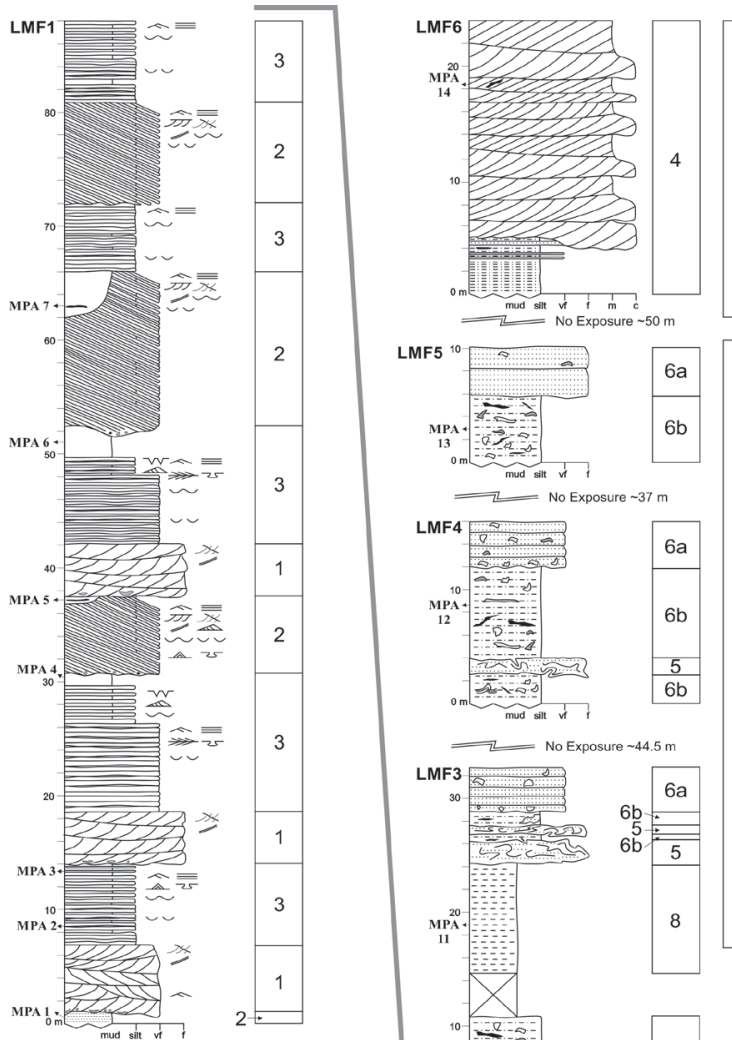

Facies Associations (FA):

1. Tidal channel deposits

2. Tidal point bar deposits

3. Tidal flat deposits

4. Delta front deposits
Slump deposits

5. Slump deposits

6a. Sandy debrite
6abrite

Lacustrine mud deposits

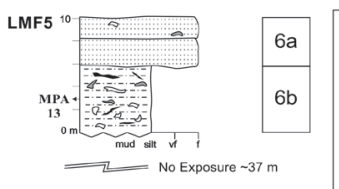

Legend

Dग Cross bedding

- Unidirectional ripple

$\Longrightarrow$ Bidirectonal ripple

Planar lamination

Reactivation surface

LMF4

F4 4

Mud/carbonaceous d

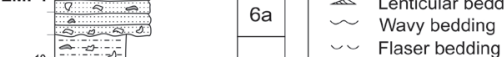

$=0$

sSs Slump bedding

i.: Normal grading

¿ू. Sand clast

sa Mud clast

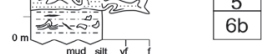

Z Carbonaceor

LMF3 No Exposure $-44.5 \mathrm{~m}$

25 Load structure

a. Tepee structure

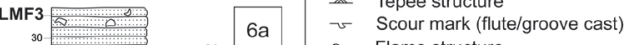

$6 \mathrm{~b}$ - 5 Flame structure

$6 \mathrm{~b}=20$ Plant fragmen

$\underset{11}{M^{20}}$

MPA 2* Palynological sample

Abbreviation: $v=v e r y$ fine sand, $f=$ fine sand,

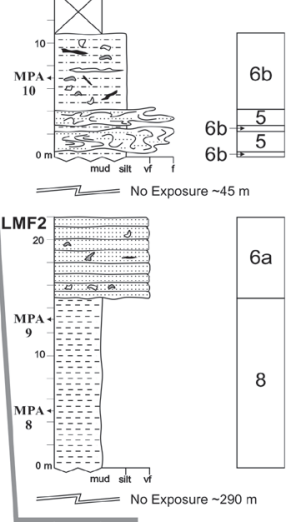

FIGURE 2. Composite vertical outcrop measured section of the Mapia section 
The distinctive tidal indicator in this FA is the presence of mud drapes separating packages of foresets forming tidal bundles in cross-beds (Boyd et al. 2006; Hughes 2012; Longhitano et al. 2012; Santos \& Rossetti 2006). Tidal bundles are formed as a result of periodic variations in tidal energy where the sandier deposits relate to spring tides higher-energy periods and muddier deposits to neap tides lower-energy periods (Hughes 2012). Reactivation surfaces separating cross-stratification form as a consequence of momentary arrest of the current during the slack water periods (Longhitano et al. 2012). Therefore, FA 1 is interpreted as tidal channel deposits.

\section{FACIES ASSOCIATION 2 (FA 2): TIDAL POINT BAR DEPOSITS}

Description: FA 2 consists of two facies: inclined heterolithic stratification (IHS) facies and mudstone dominated facies (Figure 4(B), 4(C) \& 4(D)). The IHS composed of an alternation of moderately to well-sorted, very fine-grained sandstone, siltstone, and mudstone. The master IHS surfaces dip from 10 to $20^{\circ}$. The base of IHS units is typically erosional with pebble to cobble mud clast breccia locally found above the erosional surface.
Beds range in thickness from a few $\mathrm{cm}$ to $\mathrm{dm}$ with common sharp contact between sandstone/siltstone with the mudstone bed. The sandstone and siltstone beds are generally unidirectional rippled cross-lamination, and less commonly cross-stratified with mud draped laminae separating the cross-bed. Individual sets of the cross-bed are $10-30 \mathrm{~cm}$ thick. Reactivation surfaces and opposite dipping foresets of the cross strata are found locally. Rhythmic alternations of sandstone/siltstone and mudstone are observed in the IHS facies with no obvious thinning or thickening upward trend. Mudstone dominated facies is found above IHS facies with sharp contact. It is up to $4 \mathrm{~m}$ in thickness and gradually tapering out to a zero-edge against adjacent IHS facies. These facies predominantly consist of laminated or structureless mudstone and carbonaceous siltstone layer with asymmetric variable thickness. Locally, mudstone layers interbedded with coaly mudstone layer and very fine-grained sandstone. The sandstone beds and coaly intervals typically less than $10 \mathrm{~cm}$ thick. FA 2 reaches $14 \mathrm{~m}$ in thickness. Other sedimentary structures found in this FA are parallel laminae, flaser, wavy and lenticular bedding, and soft-sediment deformation (slumped/tepee layer and load/sinking structures).
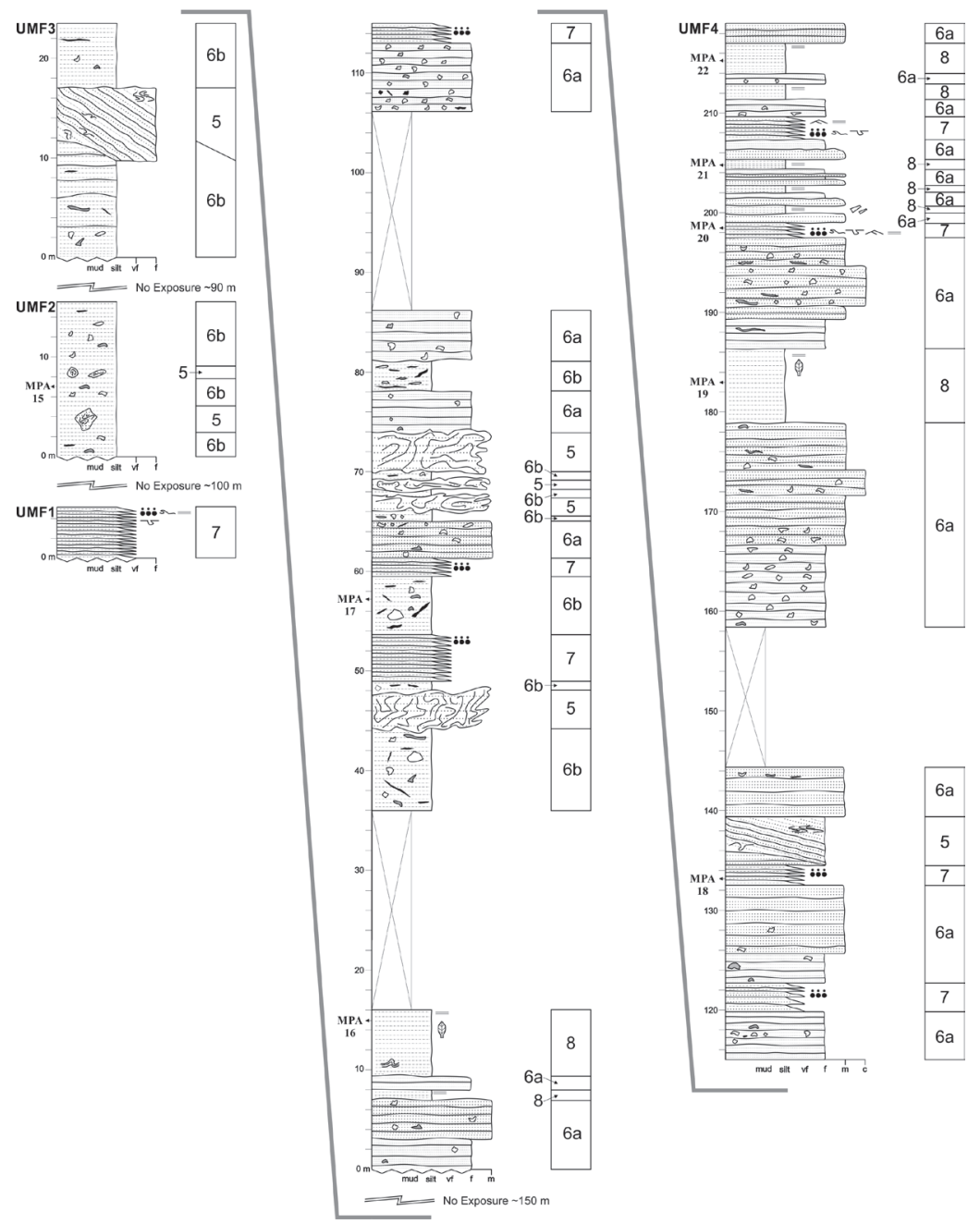

FIGURE 3. Composite vertical outcrop measured section of the Moanemani section (Legend and abbreviation: see Figure 2) 

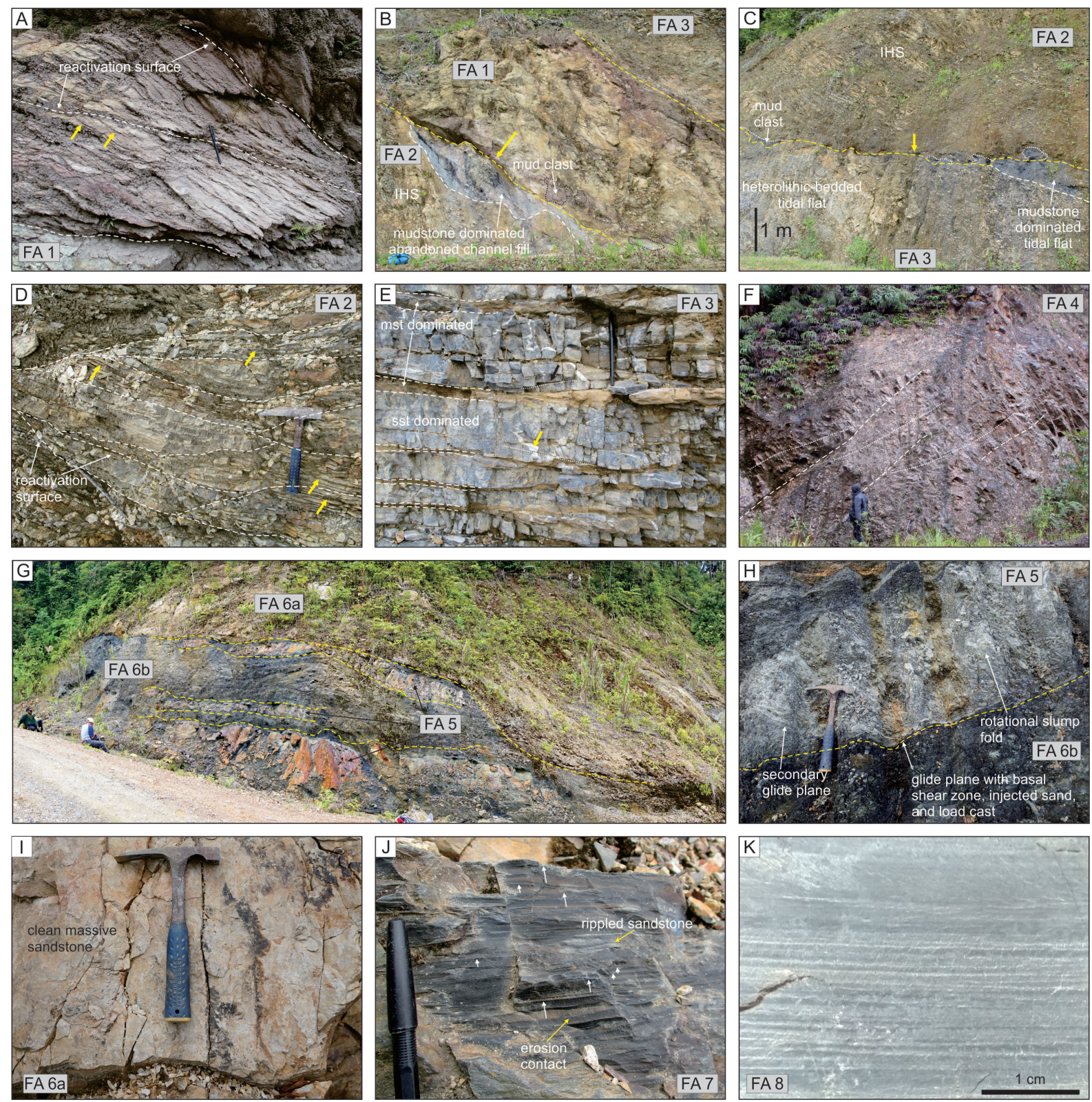

FIGURE 4. Field photographs of the studied outcrops (A) Cross-stratified sandstone of FA 1 with reactivation surfaces (white arrows) and mud drapes (yellow arrows), (B) Erosional base of FA 1 (yellow arrows) and mud clasts above the erosional surface, (C) IHS deposits with mud-clast breccia above the erosional surface, (D) Reactivation surfaces (white arrows) and mud drapes (yellow arrows) in the cross-stratified sandstone of FA 2, (E) Rhythmic alternations of sandstone dominated and mudstone dominated interval of FA 3. The ripple cross-laminated commonly unidirectional (yellow arrows) with rare opposite direction (black arrow), (F) Cross-bedded sandstones of distributary channel deposit of FA 4, (G) Interbedded of deformed sandstone (FA 5) with muddy debrite (FA 6b) and capped by sandy debrite (FA 6a), (H) The slump folds, primary and secondary glide planes, injected sand, and load cast of FA 5, (I) Clean massive sandstone of FA 6a, (J) Normal grading sandstone to siltstone interbedded with mudstone (white arrows) with rippled sandstone forming rhythmic bedding, and (K) Planar laminae of mudstone and siltstone 
Interpretation: IHS is commonly associated with point bars of meandering tidal channels, representing lateral accretion, which formed as sediment accumulates across a sloping face either through suspended or bedload deposition (Dalrymple \& Choi 2007; Dalrymple et al. 1992; Hughes 2012). The IHS deposits can lie with an angle of repose between 1 and $30^{\circ}$, and if bedforms were present during formation may exhibit cross-stratification (Hughes 2012). Reactivation surfaces and mud drapes can occur within the predominantly unidirectional cross-beds allowing the recognition of tidal bundles and tidal-bundle sequences, and will be most abundant during low stages of the river (Dalrymple \& Choi 2007). The current ripples are an indication of a relatively moderate-energy environment and the different types of rippled subfacies (wavy, flaser, or lenticular bedding) caused by a variable amount of mud in the system (Olariu et al. 2015). Tidal rhythmites are possibly developed during times of low river flow in the fine-grained deposits, even though the area contains freshwater (Dalrymple \& Choi 2007; Gugliotta et al. 2016). Mud clast breccias are probably the result of upstream point bar erosion during fluvial or tidal flooding periods (Musial et al. 2012). Mudstone dominated unit is interpreted as an abandoned channel fill deposit. The presence of horizontal lamination and carbonaceous and coaly layer suggest sedimentation controlled by mud settling during long periods and, a high organic contribution during deposition from emergent vegetated areas result from tidal or river floods (Musial et al. 2013, 2012). The syn-sedimentary deformation might be initiated by water release during sedimentation (Musial et al. 2012) or deformed by loading, which indicates a rapid emplacement during an abrupt depositional event such as a river flood or marine storm (Olariu et al. 2015). Therefore, FA 2 is interpreted as tidal point bar deposits.

\section{FACIES ASSOCIATION 3 (FA 3): TIDAL FLAT DEPOSITS}

Description: FA 3 is composed of two facies: heterolithicbedding and thicker mudstone layer (Figure 4(C) \& 4(E)). Heterolithic bedding consists of very fine-grained sandstone, siltstone, and mudstone. The sandstones are moderately to well sorted. Common unidirectional ripple cross-laminated is found in sandstone and siltstone layers with rare bidirectional ripple cross-laminated. The sandstone and siltstone beds are commonly look lens like and can be amalgamated, forming $\mathrm{cm}$ to $\mathrm{dm}$ thick beds, which separated by $\mathrm{cm}$ thick mud layers typically with sharp contacts. Mudstone facies is $50 \mathrm{~cm}$ to $2.5 \mathrm{~m}$ in thickness, locally carbonaceous with thin siltstone and very fine-grained sandstone intercalation. An overall fining- and thinning-upward succession can be observed in this facies association (Figure 2). Other sedimentary structures observed in this FA, such as rhythmic bedding, parallel laminae, flaser, wavy, and lenticular bedding, soft-sediment deformation (slumped/tepee layer and load/ sinking structures), and mud crack. The minor fault also occurred. FA 3 is up to $12 \mathrm{~m}$ thick.

Interpretation: Heterolithic-bedded indicates a depositional setting with alternating traction sediment transport and deposition from suspensions (Collinson 1996; Santos \& Rossetti 2006). The overall fining- and thinning-upward succession with tidal rhythmites are an indication of tidal-flat deposition (Fan 2013). The upward change in thickness of sand/mud packages from thicker to thinner upward suggests tidal currents as the primary depositional process (Santos \& Rossetti 2006) Soft-sediment deformation found in this FA is interpreted to form with the same process of the deformed layer of FA 2. Observed mud crack structures suggest subaerial exposure and indicate intertidal setting (Lasemi et al. 2012; Tucker \& Wright 1990). The minor fault is interpreted as syn-sedimentary fault produced by penecontemporaneous deformation resulting from the movement of muddy semi consolidated sediment under the influence of gravity (Boggs 2012; Reineck \& Singh 1980).

\section{FACIES ASSOCIATION 4 (FA 4): DELTA FRONT DEPOSITS}

Description: FA 4 consists of moderately to poorly-sorted, medium-grained to coarse-grained sandstone. They are erosionally based, show fining-upward trends, with common trough cross-beds and locally rip-up mud clasts (Figure 4(F)). Beds are up to $2 \mathrm{~m}$ thick. The cross-bedded sandstones are overlaying the interbedded of very finegrained sandstone and siltstone lamination, which shows coarsening- and thickening-upward succession (Figure 2). FA 5 is up to $24 \mathrm{~m}$ thick and only found at the very top of the Mapia section.

Interpretation: The cross-bedded sandstones with erosional based, fining-upward trends and rip-up mud clasts are interpreted as terminal distributary channel deposits (Olariu \& Bhattacharya 2006). The associated interbedded of very fine-grained sandstone and siltstone lamination with coarsening- and thickening-upward are interpreted as mouth-bar deposits (Schomacker et al. 2010). Terminal distributary channels are located at the very end of distributary channel systems within the delta front and infilling by the intimately associated mouth-bar deposits (Olariu \& Bhattacharya 2006). 
FACIES ASSOCIATION 5 (FA 5): SLUMP DEPOSITS

Description: FA 5 is primarily composed of deformed fine- to medium-grained bedded sandstone (Figure $4(\mathrm{G}) \& 4(\mathrm{H}))$. The deformation structures observed in the sandstone such as slump folds, glide planes, minor faults, and steeply dipping layers. The deformed bedded sandstone commonly found as a large sandstone block enclosed in the siltstone matrix with irregular upper and bottom contact. The large sandstone block shows lenticular to sheet-like geometry with irregular thickness. Locally, a coaly siltstone clast found in the matrix surrounding the sandstone blocks. The associated interbedded siltstone is usually undeformed. Feature such as sand injection and load cast can be observed in the siltstone. Uncommon siltstone and heterolithic facies with steeply dipping and truncated layers also observed. The deformed layers/FA 5 reach a thickness of $4 \mathrm{~m}$.

Interpretation: Sedimentary features such as slump folds, rotational slumps, glide planes with basal shear zones, minor fault, and steeply dipping layers in the deformed unit interbedded with undeformed layers are general characteristics of slumps deposit (Shanmugam 2018). Slump fold is an intraformational folding produced by soft-sediment deformation (Shanmugam 2018). The primary glide plane shown by basal shear zone is the base part of the slumped unit that has been crushed and brecciated by many fractures due to shear strain (Shanmugam 2018). A secondary glide plane is the slip surface along where major displacement occurs, which suggests internal soft-sediment deformation as well as the steeply dipping layers (Liu et al. 2017b; Shanmugam 2018). Minor faults in the deformed sand layer suggest internal fractures as a result of extension due to slumping movements (Liu et al. 2017a; Madon 2010). The rotational slumps and floating sandstone blocks suggest deposition in a gravitationally unstable slope condition (Madon 2010). Coaly siltstone clast suggests sediment failure from delta plain sediment.

\section{FACIES ASSOCIATION 6 (FA 6): DEBRITE}

Description: FA 6 is divided into sandy debrite (FA 6a) and muddy debrite (FA 6b). It is the most widespread FA in the study area. FA 6 a is composed of massive sandstone with floating clasts and clean massive sandstone. The massive sandstone with floating clasts facies consists of very fine- to medium-grained sandstone with subordinate coarse-grained sandstone, moderately to poorly sorted, with various floating sand, coaly siltstone, and mud/ carbonaceous clasts (Figure 4(G)). The clasts vary in size ( $1 \mathrm{~cm}$ to more than $20 \mathrm{~cm}$ ), shape (angular to subrounded), orientation (planar to random fabrics) and position (at the base, the middle or at the top) in massive sandstone bed. The clean massive sandstone facies consist of very fine- to medium-grained sandstone, moderately to poorly sorted, lacking grading, sedimentary structures, and clasts (Figure 4(I)). The thickness of the individual bed of sandstone ranging from 2 to $3 \mathrm{~m}$. FA 6a display geometry of lenticular to sheet/tongue-like shapes with the amalgamated units reach a thickness of $20 \mathrm{~m}$.

FA $6 \mathrm{~b}$ is composed of black carbonaceous siltstones with floating sand, coaly siltstone, and mud/carbonaceous clasts (Figure $4(\mathrm{G}) \& 4(\mathrm{H}))$. The clast varies in size $(1$ $\mathrm{cm}$ to more than $20 \mathrm{~cm}$ ), with the dominant of the clast are less than $10 \mathrm{~cm}$. The shape of the clasts is angular to subrounded, with most of the clasts are in the planar fabrics. The floating position of the clasts is varying at the base, middle, or top of the siltstone bed. Sandstone clast is commonly deformed and elongated. FA $6 \mathrm{~b}$ is up to 12 $\mathrm{m}$ thick. Commonly, the bottom contact of FA 6 is abrupt, and the top contact surfaces are sharp and irregular.

Interpretation: The presences of floating clasts in sandy and muddy matrix, irregular sharp upper contacts, and lenticular to sheet tongue-like shapes geometry are general characteristics of debrite deposit (Shanmugam 2018). Downslope mass-transport processes with plastic rheology and laminar state triggered by slumping of the actively deforming delta-slope system depositing debris flow deposit through freezing en masse (Madon 2010; Shanmugam 2018). The planar clast alignment indicates laminar flow conditions of debris flows with strength (Liu et al. 2017a; Zou et al. 2012). The random fabrics of floating clasts represent the final position of clasts at the final time of deposition (Enos 1977; Hampton 1972; Liu et al. 2017a; Shanmugam et al. 1994). The irregular sharp upper contacts of the clean massive sandstone facies also suggest that this unit was deposited by the freezing en masse of sandy debris flow (Liu et al. 2017b; Shanmugam 2018; Talling et al. 2012). The resulted debrite (sandy or muddy) is most likely controlled by the nature of delta/ shelf deposit (sand-rich or mud-rich) (Shanmugam 2018).

\section{FACIES ASSOCIATION 7 (FA 7): TURBIDITE}

Description: FA 7 is mainly light gray very fine to finegrained sandstone, dark gray siltstone interbedded with black mudstone forming rhythmic bedding (Figure 4(J)). Normal grading can be observed. The normal grading single unit package is from less than 2 to $10 \mathrm{~cm}$ thick and usually has multi-stages stacking together, making up several cycles in the section. Locally, the sand rippled layer interbedded with the mudstone. The bottom of the 
sandstone has a sharp planar or erosion contacts with groove casts, flute casts, and flame structures. FA 7 reaches a maximum thickness of $5 \mathrm{~m}$.

Interpretation: The normal grading profiles of FA 7 are interpreted as deposits of turbidity currents. The decreases of velocity in a waning flow of surge-like, turbulent gravity flow would deposit coarse-grained material first followed by fine-grained material, forming normal grading facies (Liu et al. 2017a; Shanmugam 2018; Zou et al. 2012). The sand rippled interval is attributed to traction current, which by Lowe (1982) is considered as deposits of low-density turbidity currents while by Shanmugam (2017) considered as deposits of bottomcurrent reworking. Erosion surface with groove and flute casts at the bottom of the turbidite sequence suggests the erosive activity of turbulent flow (Liu et al. 2017a; Zou et al. 2012). The loading of sands above water-saturated muddy layers caused water escape structures such as flame structure (Boggs 2012).

\section{FACIES ASSOCIATION 8 (FA 8): LACUSTRINE MUD DEPOSITS}

Description: FA 8 is composed of black-dark grey carbonaceous mudstone and siltstone. Planar laminae are present (Figure 4(K)). Pyrite, plant fragments, and leave plant fossils occurred locally in this FA. The thickness of the FA 8 reaches $15 \mathrm{~m}$ in the study area.

Interpretation: The thick black mudstone and siltstone suggest deposition in a reducing and weak hydrodynamic condition (Liu et al. 2017b). Mudstone and siltstone with planar laminae are interpreted to be deposited by suspension fallout in a quiet-water environment ( $\mathrm{Li}$ et al. 2018; Zou et al. 2012). The presence of pyrite-containing interval in carbonaceous mudstone and sandstone suggests a reducing and stable deep-water environment (Berner 1984). The plant fragments and leave plant fossils generally only preserves in acidic anoxic conditions environment such as the bottom of lakes, abandoned channels, and in swamps or river deltas (Greenwood 1991). From the palynological analysis, the presence of freshwater green algae, such as Zygnema type and Botryococcus sp., without the occurrence of marine palynomorphs indicate a freshwater depositional environment. Therefore, FA 8 is interpreted to represent suspension fallout deposits in shallow and deep-water lacustrine settings.

\section{BIOSTRATIGRAPHY}

The palynomorphs show high diversity with a total of 61 distinct palynomorph types, which divided into 24 pollen,
22 spores, and 15 non-pollen and spores palynomorph. Preservational quality is from barren (three samples), poor (less than 50 grains, 13 samples), and moderate (50-150 grains, six samples). The generally low counts recovery of palynomorphs is probably due to either unfavorable conditions during deposition or the effects of post-depositional weathering. These low preservational qualities, nevertheless, is adequate for biostratigraphic zonation purposes. Pollen and spore distribution of the analyzed samples is presented in Figure 5. Selected palynomorph types are illustrated in Figure 6.

Palynological zonation of the studied samples (Figure 5) are divided into: First, the interval of samples MPA5 to MPA7 is characterized by the co-occurrence of Nothofagus brassii type pollen (Nothofagus emarcida), Foveosporites sp., and Metroxylon type, without the presence of Malvacipollis diversus. This interval is assigned to the Metroxylon salomonense to Nothofagidites emarcida Zone, which is of Middle Miocene to Early Pliocene age (Lelono 2007). This zone recorded the initial presence of Australian plant elements such as Casuarina type, Dacrydium pollen (Lygistepollenites florinii), Nothofagus brassii type pollen, Phyllocladus pollen, and Podocarpus sp. (Morley 2011, 1998).

Second, the first occurrence of Malvacipollis diversus in sample MPA 8 characterizes the interval of samples MPA8 to MPA14. Garcinia cuspidata type is absent in this interval. This zone is assigned to the Malvacipollis diversus Zone, which is of Late Pliocene age (Lelono 2007). The initial occurrence of Stenochlaena milnei type is notable in this zone.

Third, the interval of samples MPA15 to MPA18 is characterized by the first occurrence of Garcinia cuspidata type in sample MPA15, without the occurrence of Proteacidites sp. in the interval. This interval is assigned to the Garcinia cuspidata type Zone, which is of Late Pliocene age (Lelono 2007). Noteworthy is the initial occurrence of Dacrydium guillauminii type in this zone. Fourth, the interval of samples MPA19 to MPA22 is characterized by the first occurrence of Proteacidites sp. at its bottom. This zone is assigned to the Proteacidites sp. Zone, which is of Pleistocene age (Lelono 2007). Ericaceae pollen and Podocarpidites sp. initially occurs in this zone.

The first $30 \mathrm{~m}$ of the studied samples (MPA1 to MPA4 of Mapia section) is barren or rarely contains palynomorphs, none of which are marker species. No age can be assigned to this interval. Nevertheless, considering its conformable succession with its above zone (Metroxylon type-Nothofagus emarcida Zone), it 
is interpreted that this interval is also Middle Miocene in age. The youngest biozonation of the Mapia section is the Malvacipollis diversus Zone, while the oldest biozonation of Moanemani section is the Garcinia cuspidata type Zone. This indicates that the Moanemani section is younger than the Mapia section.

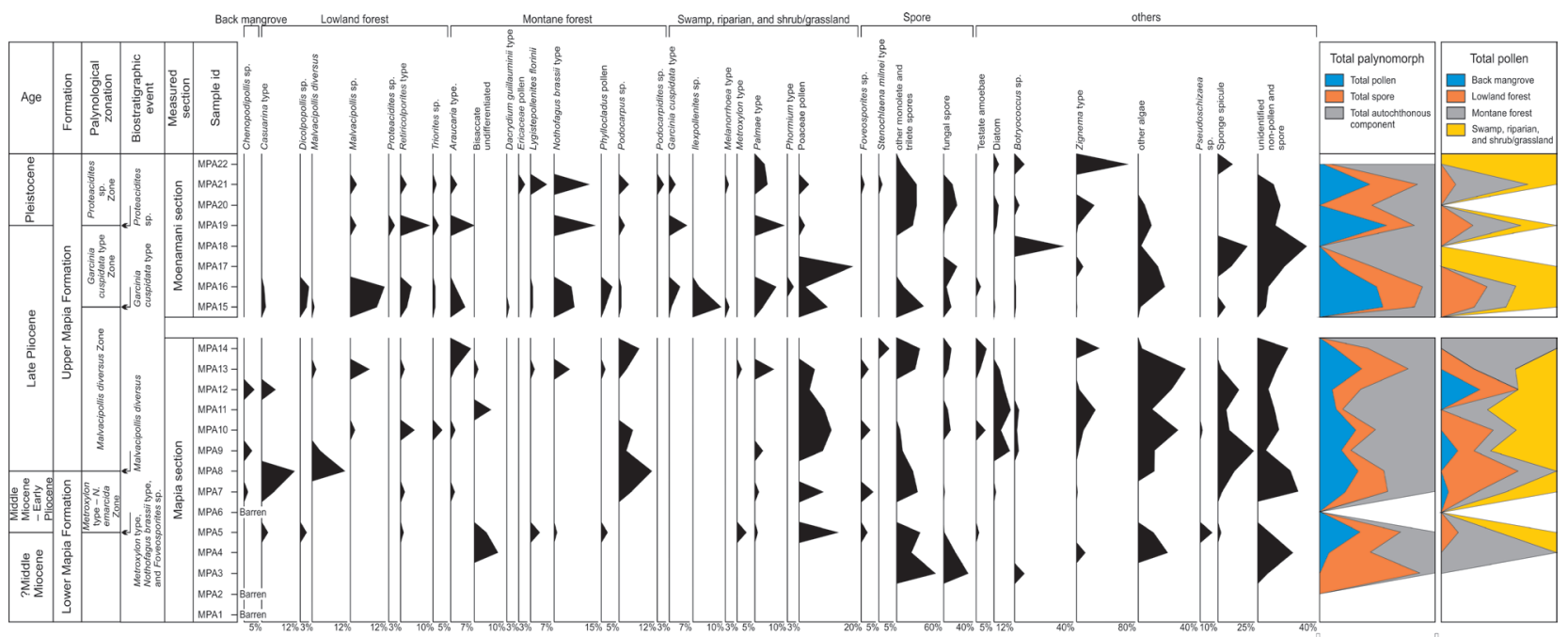

FIGURE 5. Pollen and spores distribution of the analyzed samples
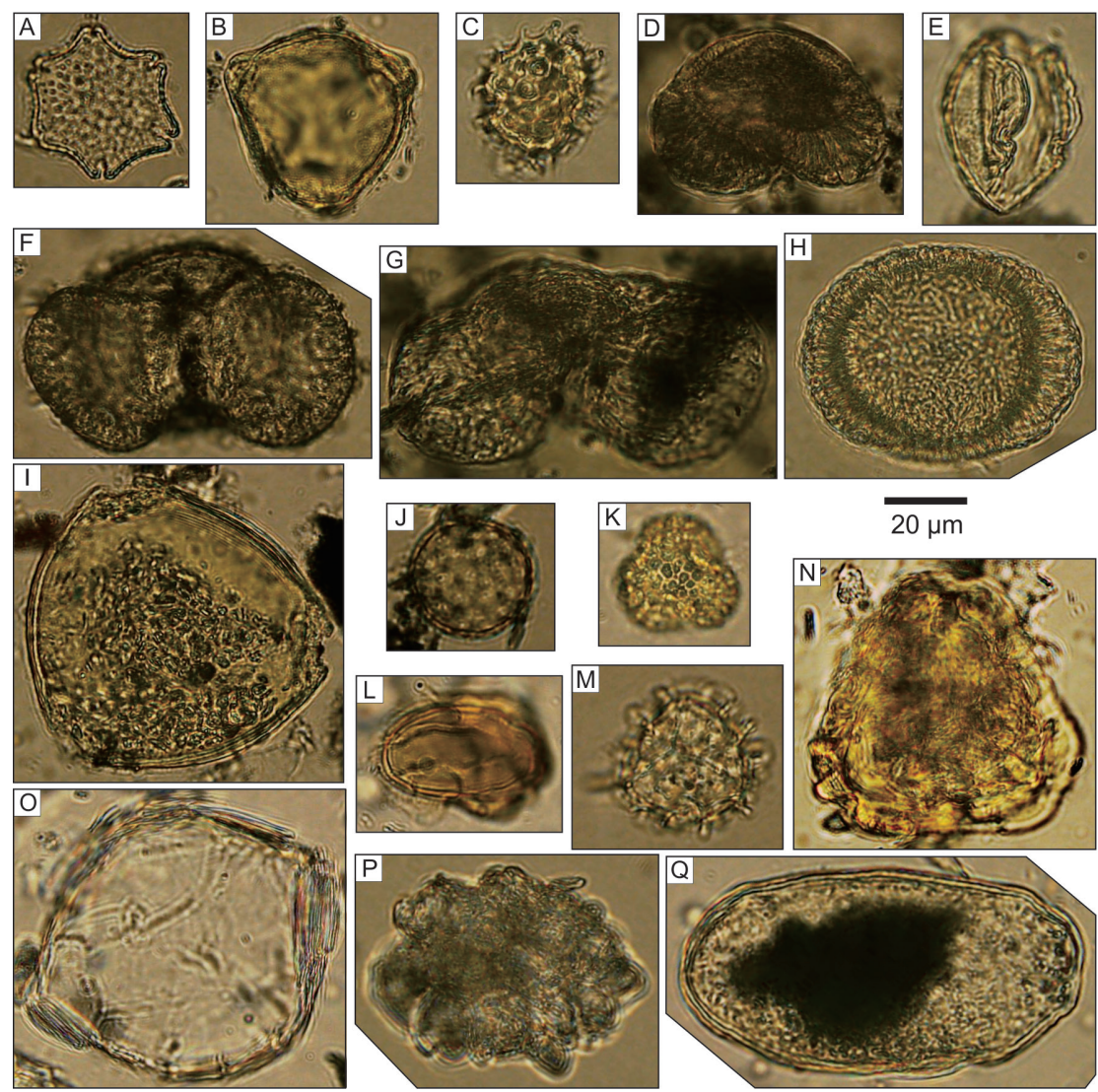

FIGURE 6. Photomicrographs of selected palynomorphs of the Mapia Formation (A) Nothofagus brassii type, (B) Casuarina type, (C) Malvacipollis diversus, (D) Lygistepollenites florinii, (E) Phyllocladus pollen, (F) Podocarpus sp., (G) Podocarpidites sp., (H) Dacrydium guillauminii type, (I) Proteacidites sp., (J) Chenopodipollis sp., (K) Ilexpollenites sp., (L) Stenochlaena milnei type, (M) Lycopodium clavatum type, (N) Pteris type, (O) Zygnema type, (P) Botryococcus sp., \& (Q) Ovoidites sp. 
DEPOSITIONAL MODELS: FLUVIAL-TIDAL DEPOSIT

Based on the facies association analysis, as mentioned earlier, a tidally dominated fluvially influenced depositional environment is suggested for the deposition of the lower part of the Mapia section (FA 1, FA 2, and FA 3) (Figures 2 and $7(\mathrm{~A})$ ). The occurrence of the tidal channel (FA 1) and IHS (FA 2) with mud drapes, tidal bundle, and rhythmic bedding is suggesting tide domination process within meandering tidal channels (Boyd et al. 2006; Longhitano et al. 2012; Olariu et al. 2015). The presence of tidal flat deposits (FA 3) above the tidal channel (FA 1) and IHS (FA 2) support the tide domination interpretation. The depositional environment is interpreted to be situated in the meandering part of the fluvial-tidal channel with mixed energy of tidal and river currents occurred (Dalrymple \& Choi 2007). The fluvial-tidal deposits model observed in the studied area is considered similar to the tide-influenced point bar model in the McMurray Formation (Hubbard et al. 2011; Musial et al. 2013, 2012). It consists of mud clast breccias at channel base, cross-stratified sands, heterolithic and rippled sands, deformed and slumped layers, and thick clay layers as channel abandonment or as flood-plain deposits at the top of the point bar.

Throughout most of the fluvial-marine transition zone, freshwater entirely occurred with brackish water conditions may be present at the seaward end of the zone, and may extend further into the zone at times of low river flow (Dalrymple \& Choi 2007). The absence of mangrove and marine palynomorphs in all the fluvial-tidal samples suggest a freshwater environment. The palynomorphs content in this fluvial-tidal deposit is dominated by swamp and shrub/grassland, lowland and montane forests origin which support the freshwater condition interpretation. The co-occurrence of diatom, freshwater algae, freshwater sponge spicule, fungal spore, Pseudoschizaea, and testate amoebae also support the interpretation. The occurrence of back mangrove palynomorph (Chenopodipollis sp.) indicates brackish water influence in top of the sequence (sample MPA7). Palynomorphs of montane rain forest such as Araucaria, Dacrydium, Nothofagus, Phyllocladus, Podocarpus, and Bisaccate undifferentiated are present in the fluvial-tidal deposits. In the present time, the mentioned plants dominate the montane rain forests (altitude 1.500-2.500 m) of Papua (Kartikasari et al. 2012). The occurrences of montane palynomorphs in the fluvialtidal deposit samples suggest that there were mountains nearby at the Middle Miocene to Early Pliocene time.

\section{FLUVIAL-LACUSTRINE DEPOSIT}

A non-channelized deep-lacustrine slump and debrisflow dominated model (Figure 7(B)) is proposed for depositional model of upper Mapia and Moenamani section, based on the recognized FA: 1. delta front deposits (FA 4), 2. slump deposits (FA 5), 3. sandy and muddy debrite (FA 6), 4. turbidite (FA 7), and 5. suspension fallout deposit/lacustrine mud (FA 8) (Liu et al. 2017a, 2017b; Shanmugam 2000; Xu et al. 2016; Zou et al. 2012). Sedimentary facies distribution in this slump and debrisflow dominated model follow the steps by Li et al. (2018) and Zou et al. (2012): 1. deltaic deposition as the source of the deep-water sandstones, 2 . subaqueous sediment failure of delta front or prodelta deposits due to earthquakes and/ or volcanoes activities, 3 . mass transport and slumping of unconsolidated sandy and muddy sediments toward the lake center, 4. mass transport and deposition of sandy or muddy debrite toward the lake center, 5. transformation of the debris flows into turbidity currents and the deposition of turbidite, and 6. the deposition of lacustrine mud from suspension fallout in both shallow and deep lacustrine settings.

The records of the freshwater green algae of Zygnema type, Botryococcus sp., Monoraphidium type, Oocystis type, Ovoidites sp., Pediastrum sp., and Treubaria type indicate a fluvial-lacustrine environment (FA 4-FA 8). Zygnemataceae are inhabiting shallow, stagnant, oxygen-rich freshwater lakes, ponds, small pools, or wet soils (van Geel 2001). Botryococcus generally lives in freshwater swamps, temporary pools, ponds, and lakes (van Geel 2001). The co-occurrence of diatom, freshwater sponge spicules, fungal spore, Pseudoschizaea, and testate amoebae, together with the absence of mangrove and marine palynomorphs also support the fluvial-lacustrine environment interpretation. The pollen and spore palynomorphs contain in these fluvial-lacustrine deposits are dominated by lowland forest, montane forest, swamp, riparian, and shrub/grassland origin. This assemblage is interpreted as allochthonous palynomorphs assemblage, transported into the lake by wind or river. Back mangrove palynomorph (Chenopodipollis sp.) found in the lower part of the fluvial-lacustrine succession (MPA9 and MPA12, Mapia section) indicate there is a coastal area near the depositional environment at Late Pliocene time (Malvacipollis diversus Zone). The absence of the back mangrove palynomorph in the upper part of the section (Garcinia cuspidata type to Proteacidites sp. Zone) suggests a change in the depositional environment towards the land away from areas of coastal vegetation. 

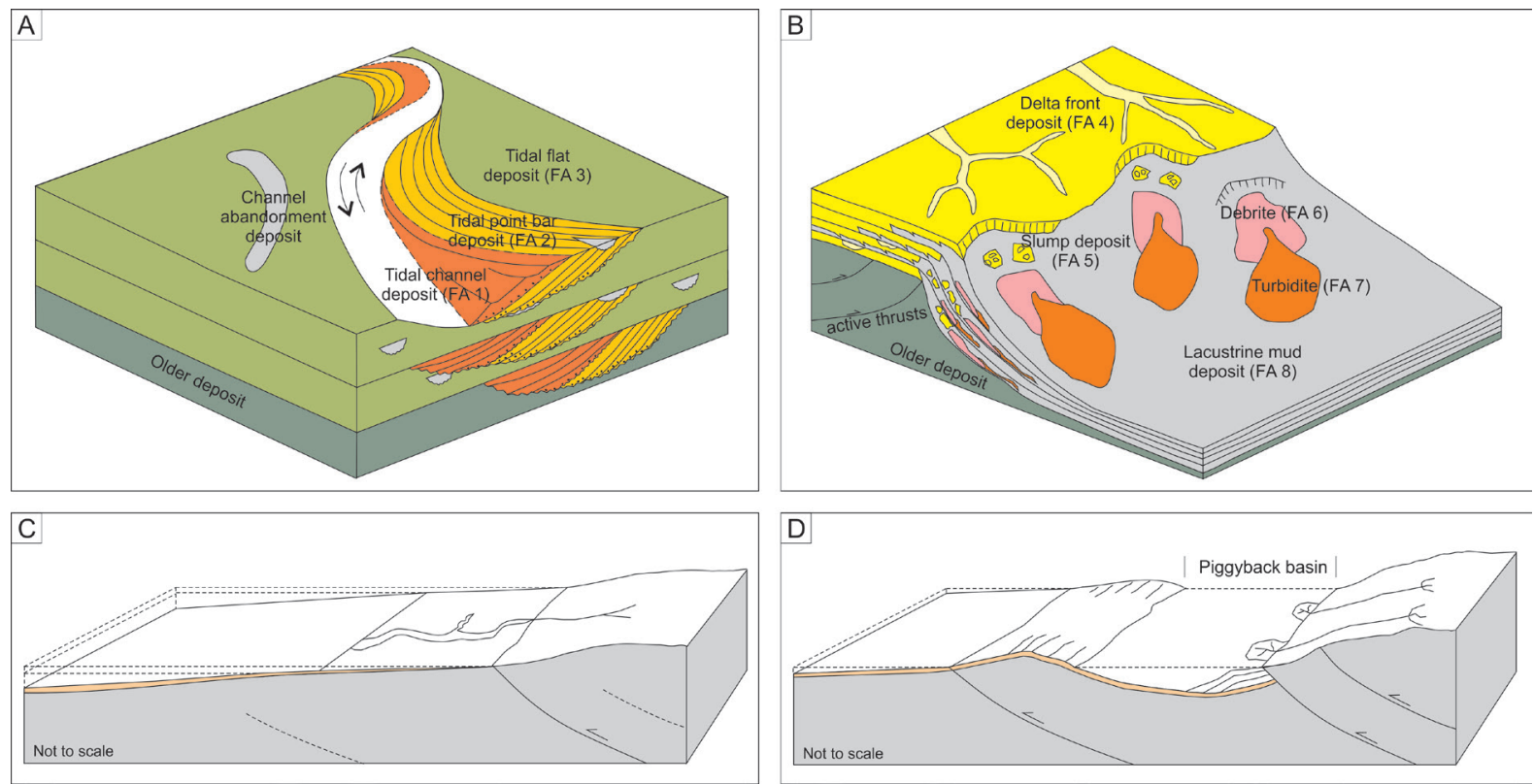

FIGURE 7. Depositional model and facies associations of tidally dominated fluvially influenced of the lower Mapia Formation (A) and non-channelized deep-lacustrine slump and debris-flow dominated of the upper Mapia Formation (B). Simplified illustration of the study area basin development. Initial stage of Central Range orogeny (C) forming fluvial-tidal deposits at Middle Miocene to Early Pliocene and major uplift event (D) forming piggyback basin with fluviallacustrine deposits at Late Pliocene to Pleistocene (modified from Cohen (2020))

NEW STRATIGRAPHIC UNIT PROPOSAL

The studied succession, which was previously considered as Permian in age called the Aiduna Formation, is being formally proposed in this paper as a new stratigraphic unit. It is designated as the Mapia Formation, referring to the Mapia village. The fluvial-tidal deposit (FA 1-FA 3) is defined as the lower Mapia Formation with distinct lithological characteristics and the depositional environment as described above with the age of Middle Miocene to Early Pliocene. The lower part of the Mapia section is also proposed as the type locality for this unit (Figure 2). On the other hand, the fluvial-lacustrine deposit (FA 4-FA 8) with the age of Late Pliocene to Pleistocene is assigned as the upper Mapia Formation. The type locality of this unit could be found in the upper part of the Mapia and Moanemani sections (Figures 2 \& 3).

\section{DISCUSSIONS OF RELATION TO TECTONICS EVENTS}

The lower Mapia Formation was deposited as synorogenic clastic sediments at the collision event of Australian passive margin strata with the Outer Melanesian arc which formed the Central Range orogeny at the latest Middle Miocene, after cessation of carbonate shelf sedimentation at about $12 \mathrm{Ma}$ (Figure 7(C); van Ufford \& Cloos (2005)). Middle Miocene to Early Pliocene montane forest palynomorphs found in the lower Mapia Formation evidenced the occurrence of the high mountain at that time. Casuarina type, Dacrydium, Nothofagus, Phyllocladus, and Podocarpus (Australian plant element) dispersed to Papua island during the Late Miocene as montane environments became established with the uplift of the Papua island mountains (Khan 1976; Morley 2011, 1998). Paleogeography reconstruction of the Australian and Papuan region at Middle Miocene to 
Early Pliocene shows that there was still a wide ocean between the study area (Papua) and Australia (Hall 2012). The closest distance between the study area and Australian land was at about $10 \mathrm{Ma}$ (Late Miocene). It is speculated that there was a hopping island as a plant dispersal route between the two areas, probably the terrestrial remnant of equivalent Oligocene Sirga Formation (van Ufford \& Cloos 2005). The distribution and chronostratigraphic relation of the synorogenic clastic sediments during Central Range orogeny have been discussed by van Ufford and Cloos (2005). The lower Mapia Formation is the fluvial-tidal part and age correlating with the Klasaman, Akimeugah, Iwur, and lower Buru formations, which are more marine origin (van Ufford \& Cloos 2005).

The upper Mapia Formation was deposited in Late Pliocene to Pleistocene time when the topography of the Central Range was similar to that of today (van Ufford \& Cloos 2005). It is most probably deposited in the piggyback basin between the low lying fold and thrust belt of Papua (Figure 7(D); Cohen (2020); Hill \& Hall (2003)) when the major uplift event occurred in the Central Range. The major uplift event in eastern New Guinea took place in a similar time, at about $4 \mathrm{Ma}$ (Abbott 1995; van Ufford \& Cloos 2005). Active tectonic activity during deposition of the upper Mapia Formation characterized by the common presence of slump deposits in the unit, which was triggered by the earthquake. The upper Mapia Formation is the fluvial-lacustrine part and age correlating with the Sele (terrigenous), Steenkool (deltaic), Dakebo (terrigenous), upper Buru (shallow marine-terrigenous), and Birim (terrigenous) which marked rapid erosion and deposition in the active thrust belt setting (van Ufford \& Cloos 2005). Furthermore, the upper Mapia Formation is considered as formed in the wedge-top depozone of the Neogene Papuan foreland basin system, while the upper Buru Formation was accumulated in the foredeep depozone.

\section{CONCLUSION}

The lower Mapia Formation was deposited at Metroxylon type to Nothofagus emarcida Zone, Middle Miocene to Early Pliocene, during the beginning of Central Range orogeny. It is comprised of three facies associations: tidal channel, tidal point bar, and tidal flat deposits. A tidally dominated fluvially influenced depositional environment is suggested for the deposition of sediments of this unit.

The upper Mapia Formation was deposited at Malvacipollis diversus Zone, Garcinia cuspidata type Zone, and Proteacidites sp. Zone, Late Pliocene to Pleistocene, during the major uplift event. It is comprised of five facies associations: delta front, slump, debrite, turbidite, and lacustrine mud deposits. A non-channelized deep-lacustrine slump and debris-flow dominated depositional environment is suggested for the deposition of sediments of this unit.

\section{ACKNOWLEDGEMENTS}

Pusat Survei Geologi, Badan Geologi, Kementerian Energi dan Sumber Daya Mineral of Indonesia supports the fieldwork and laboratory facilities. The author is grateful to Andri Perdana Putra, Eriko Sabra, Gadis Ghia Arvyalin, and Herwinsyah for their help during the fieldwork. The author is indebted to Ani Khrisnawati and Sumarjadi for their help during the laboratory process. The author wishes to thank Eko Budi Lelono and Hermes Panggabean for helpful advice regarding the palynology and geology of Papua. The author is also thankful to two anonymous reviewers, who provided constructive comments that improved the earlier version of the manuscript.

\section{REFERENCES}

Abbott, L.D. 1995. Neogene tectonic reconstruction of the Adelbert-Finisterre-New Britain collision, northern Papua New Guinea. Journal of Southeast Asian Earth Sciences 11: 33-51.

Allen, J.R.L. 1963. The classification of cross-stratified units, with notes on their origin. Sedimentology 2(2): 93-114.

Atmawinata, S., Hakim, A.S. \& Pieters, P.E. 1989. Geological Map of the Ransiki Sheet, Irian Jaya. 1:250,000. Bandung: Geological Research and Development Center.

Baillie, P.W., Fraser, T.H., Robert, H. \& Myers, K. 2004. Geological development of eastern Indonesia and the northern Australia collision zone: A review. Special Publication - Northern Territory Geological Survey 2004: 539-550.

Berner, R.A. 1984. Sedimentary pyrite formation: An update. Geochimica et Cosmochimica Acta 48(4): 605-615.

Boggs, S. 2012. Principles of Sedimentology and Stratigraphy. 5th Ed. Hoboken: Pearson Prentice Hall.

Boyd, R., Dalrymple, R.W. \& Zaitlin, B.A. 2006. Estuarine and incised-valley facies models. In Facies Models Revisited, edited by Posamentier, H.W. \& Walker, R.G. Oklahoma: SEPM Special Publication 84, pp. 171-235.

Chung, K.W., Sum, C.W. \& Rahman, A.H.A. 2015. Stratigraphic succession and depositional framework of the Sandakan formation, Sabah. Sains Malaysiana 44(7): 931-940.

Cohen, A. 2020. Deposystem Evolution in the Foreland Basin Lakes of South America. The Arizona Board of Regents. Accessed on 16 March 2020.

Collinson, J.D. 1996. Alluvial sediments. In Sedimentary Environments: Processes, Facies and Stratigraphy, edited by Reading, H.G. Oxford: Blackwell Science. pp. 37-82. 
Collinson, J.D. 1969. The sedimentology of the Grindslow Shales and the Kinderscout Grit: A deltaic complex in the Namurian of northern England. Journal of Sedimentary Petrology 39: 194-221.

Dalrymple, R.W. \& Choi, K. 2007. Morphologic and facies trends through the fluvial-marine transition in tidedominated depositional systems: A schematic framework for environmental and sequence-stratigraphic interpretation. Earth-Science Reviews 81: 135-174.

Dalrymple, R.W., Zaitlin, B.A. \& Boyd, R. 1992. Estuarine facies models; conceptual basis and stratigraphic implications. Journal of Sedimentary Research 62(6): 1130-1146.

Enos, P. 1977. Flow regimes in debris flow. Sedimentology 24(1): 133-142.

Fan, D. 2013. Classifications, sedimentary features and facies associations of tidal flats. Journal of Palaeogeography 2(1): 66-80.

Greenwood, D.R. 1991. The taphonomy of plant macrofossils. In The Processes of Fossilization, edited by Donovan, S.K. New York: Columbia University Press. pp. 141-169.

Gugliotta, M., Flint, S.S., Hodgson, D.M. \& Veiga, G.D. 2016. Recognition criteria, characteristics and implications of the fluvial to marine transition zone in ancient deltaic deposits (Lajas Formation, Argentina). Sedimentology 63: 19712001.

Hall, R. 2012. Sundaland and Wallacea: Geology, plate tectonics and palaeogeography. In Biotic Evolution and Environmental Change in Southeast Asia edited by Gower, D.J., Richardson, J.E., Rosen, B.R., Rüber, L. \& Williams, S.T. Cambridge: Cambridge University Press. pp. 32-78.

Hampton, M.A. 1972. The role of subaqueous debris flow in generating turbidity currents. Journal of Sedimentary Research 42(4): 775-793.

Harahap, B.H. 2012. Tectonostratigraphy of the southern part of Papua and Arafura Sea, Eastern Indonesia. Indonesian Journal of Geology 7(3): 167-187.

Harahap, B.H. 1997. The metamorphic complex of the central range of Papua with special reference to the Enarotali Quadrangle. Journal of Geology and Mineral Resources 7(67): 16-25.

Harahap, B.H., Hakim, A.S. \& Dow, D.B. 1990. Geological Map of the Enarotali Sheet, Irian Jaya. 1:250,000. Bandung: Geological Research and Development Center.

Hassan, M.H.A., Sim, Y.B., Peng, L.C. \& Rahman, A.H.A. 2013. Facies analysis of the uppermost Kubang Pasu formation, Perlis: A wave-and storm-influenced coastal depositional system. Sains Malaysiana 42(8): 1091-1100.

Hill, K.C. \& Hall, R. 2003. Mesozoic-Cenozoic evolution of Australia's New Guinea margin in a west Pacific context. Special Paper of the Geological Society of America 372: 265-290.

Hubbard, S.M., Smith, D.G., Nielsen, H., Leckie, D.A., Fustic, M., Spencer, R.J. \& Bloom, L. 2011. Seismic geomorphology and sedimentology of a tidally influenced river deposit, lower Cretaceous Athabasca oil sands, Alberta, Canada. AAPG Bulletin 95(7): 1123-1145.
Hughes, Z.J. 2012. Tidal channels on tidal flats and marshes. In Principles of Tidal Sedimentology, edited by Davis, R.A. \& Dalrymple, R.W. Dordrecht: Springer. pp. 269-300.

Hutchison, C.S. 1989. Geological Evolution of South-East Asia. Oxford: Clarendon Press.

Kartikasari, S.N., Marshall, A.J. \& Beehler, B.M. 2012. Ekologi Papua, Seri Ekologi Indonesia, Jilid VI. Jakarta: Yayasan Pustaka Obor Indonesia dan Conservation International.

Khan, A.M. 1976. Palynology of tertiary sediments from Papua New Guinea. II. Gymnosperm pollen from upper tertiary sediments. Australian Journal of Botany 24(6): 783-791.

Lasemi, Y., Jahani, D., Amin-Rasouli, H. \& Lasemi, Z. 2012. Ancient carbonate tidalites. In Principles of Tidal Sedimentology, edited by Davis, R.A \& Dalrymple, R.W. Dordrecht: Springer. pp. 567-607.

Lelono, E.B. 2007. Zonasi polen tersier Indonesia timur. Lembaran Publikasi Lemigas 41(1): 1-8.

Li, X., Liu, H., Pan, S., Chen, Q., WanYan, R., Xu, W., Wang, H., Huang, J. \& Wang, J. 2018. Subaqueous sandy masstransport deposits in lacustrine facies of the upper triassic Yanchang formation, Ordos Basin, Central China. Marine and Petroleum Geology 97: 66-77.

Liu, J., Xian, B., Wang, J., Ji, Y., Lu, Z. \& Liu, S. 2017a. Sedimentary architecture of a sub-lacustrine debris fan: Eocene Dongying depression, Bohai Bay Basin, east China. Sedimentary Geology 362: 66-82.

Liu, X., Ding, X., Zhang, S. \& He, H. 2017b. Origin and depositional model of deep-water lacustrine sandstone deposits in the $7^{\text {th }}$ and $6^{\text {th }}$ members of the Yanchang formation (Late Triassic), Binchang area, Ordos Basin, China. Petroleum Science 14(1): 24-36.

Longhitano, S.G., Mellere, D., Steel, R.J. \& Ainsworth, R.B. 2012. Tidal depositional systems in the rock record: A review and new insights. In Modern and Ancient Depositional Systems: Perspectives, Models and Signatures, edited by Longhitano, S.G., Mellere, D. \& Ainsworth, R.B. Amsterdam: Sedimentary Geology Special Issue 279. pp. 2-22.

Longley, I.M. 1997. The tectonic evolution of SE Asia. In Petroleum Geology of Southeast Asia, edited by Fraser, A.J., Mathews, S.J. \& Murphy, R.W. Amsterdam: Geological Society Special Publication 126. pp. 311-339.

Lowe, R.D. 1982. Sediment gravity flows; II, Depositional models with special reference to the deposits of highdensity turbidity currents. Journal of Sedimentary Research 52(1): 279-297.

Madon, M. 2010. Submarine mass-transport deposits in the Semantan formation (Middle-Upper Triassic), central Peninsular Malaysia. Bulletin of the Geological Society of Malaysia 56: 15-26.

Morley, R.J. 1998. Palynological evidence for Tertiary plant dispersals in the SE Asian region in relation to plate tectonics and climate. In Biogeography and Geological Evolution of SE Asia, edited by Hall, R. \& Holloway, J.D. Leiden: Backhuys Publishers. pp. 211-234. 
Morley, R.J. 2011. Dispersal and paleoecology of tropical podocarps. In Ecology of the Podocarpaceae in Tropical Forests, edited by Turner, B.L. \& Cernusak, L.A. Washington DC: Smithsonian Contributions to Botany 95. pp. 21-41.

Musial, G., Labourdette, R., Franco, J. \& Reynaud, J. 2013. Modeling of a tide-influenced point-bar heterogeneity distribution and impacts on steam-assisted gravity drainage production: example from Steepbank river, McMurray formation, Canada. In Heavy-Oil and Oil-Sand Petroleum Systems in Alberta and Beyond edited by Hein, F.J., Leckie, D., Larter, S. \& Suter, J.R. Texas: AAPG Studies in Geology 64. pp. 545-564.

Musial, G., Reynaud, J., Gingras, M.K., Féniès, H., Labourdette, R. \& Parize, O. 2012. Subsurface and outcrop characterization of large tidally influenced point bars of the Cretaceous McMurray Formation (Alberta, Canada). Sedimentary Geology 279: 156-172.

Olariu, C. \& Bhattacharya, J.P. 2006. Terminal distributary channels and delta front architecture of river-dominated delta systems. Journal of Sedimentary Research 76(2): 212-233.

Olariu, C., Steel, R.J., Olariu, M.I. \& Choi, K. 2015. Chapter 10 Facies and architecture of unusual fluvial-tidal channels with inclined heterolithic strata: Campanian Neslen Formation, Utah, USA. In Developments in Sedimentology, edited by Ashworth, P.J., Best, J.L. \& Parsons, D.R. Amsterdam: Elsevier 68. pp. 353-394.

Panggabean, H. \& Pigram, C.J. 1989. Geological Map of the Waghete Sheet, Irian Jaya. 1:250,000. Bandung: Geological Research and Development Centre.

Pigram, C.J. \& Panggabean, H. 1984. Rifting of the Northern Margin of the Australian Continent and the Origin of some Microcontinents in Eastern Indonesia. Tectonophysics 107: 331-353.

Playford, G. \& Rigby, J. 2008. Permian palynoflora of the Ainim and Aiduna formations, West Papua. Revista Espanola de Micropaleontologia 40(1-2): 1-57.

Reineck, H.E. \& Singh, I.B. 1980. Depositional Sedimentary Environments. 2nd ed. Heidelberg: Springer.

Roslan, M.H.K., Ali, C.A. \& Mohamed, K.R. 2016. Fasies dan sekitaran sedimen formasi singa di Langkawi, Malaysia. Sains Malaysiana 45(12): 1897-1904.

Santos, A. \& Rossetti, D. 2006. Depositional model of the Ipixuna formation (Late Cretaceous- Early Tertiary), Rio Capim area, northern Brazil. Latin American Journal of Sedimentology and Basin Analysis 13(2): 101-117.

Schomacker, E.R., Kjemperud, A.V., Nystuen, J.P. \& Jahren, J.S. 2010. Recognition and significance of sharp-based mouthbar deposits in the Eocene Green River Formation, Uinta Basin, Utah. Sedimentology 57: 1069-1087.

Shanmugam, G. 2018. Slides, Slumps, Debris Flows, Turbidity Currents, and Bottom Currents: Implications. Amsterdam: Reference Module in Earth Systems and Environmental Sciences, Elsevier.
Shanmugam, G. 2017. Contourites: Physical oceanography, process sedimentology, and petroleum geology. Petroleum Exploration and Development 44(2): 183-216.

Shanmugam, G. 2000. 50 years of the turbidite paradigm (1950s-1990s): Deep-water processes and facies models - A critical perspective. Marine and Petroleum Geology 17(2): 285-342.

Shanmugam, G., Lehtonen, L.R., Straume, T., Syvertsen, S.E., Hodgkinson, R.J. \& Skibeli, M. 1994. Slump and debrisflow dominated upper slope facies in the cretaceous of the Norwegian and northern North Seas $\left(61-67^{\circ} \mathrm{N}\right)$ : implications for sand distribution. AAPG Bulletin 78: 910-937.

Talling, P.J., Masson, D.G., Sumner, E.J. \& Malgesini, G. 2012. Subaqueous sediment density flows: Depositional processes and deposit types. Sedimentology 59(7): 1937-2003.

Tucker, M.E. \& Wright, V.P. 1990. Carbonate Sedimentology. Oxford: Blackwell Scientific Ltd.

Van Geel, B. 2001. Non-pollen palynomorphs. In Tracking Environmental Change Using Lake Sediments. Volume 3 Terrestrial, Algal, and Siliceous indicators, edited by Smol, J.P., Birks, H.J.B. \& Last, W.M. Dordrecht: Kluwer Academic Publishers. pp. 1-17.

Van Ufford, A.Q. \& Cloos, M. 2005. Cenozoic tectonics of New Guinea. AAPG Bulletin 89(1): 119-140.

Walker, R.G. 2006. Facies models revisited: Introduction. In Facies Models Revisited, edited by Posamentier, H.W. \& Walker, R.G. Oklahoma: SEPM Special Publication 84. pp. 293-338.

Warren, P.Q. \& Cloos, M. 2007. Petrology and tectonics of the derewo metamorphic belt, west New Guinea. International Geology Review 49(6): 520-553.

Xu, Q., Shi, W., Xie, X., Manger, W., McGuire, P., Zhang, X. Wang, R. \& Xu, Z. 2016. Deep-lacustrine sandy debrites and turbidites in the lower triassic Yanchang Formation, southeast Ordos Basin, central China: Facies distribution and reservoir quality. Marine and Petroleum Geology 77: 1095-1107.

Zou, C., Wang, L., Li, Y., Tao, S. \& Hou, L. 2012. Deep-lacustrine transformation of sandy debrites into turbidites, upper triassic, central China. Sedimentary Geology 265-266: 143-155.

Centre for Geological Survey

Geological Agency

Ministry of Energy and Mineral Resources

Jl. Diponegoro No.57 40122 Bandung

Jawa Barat

Indonesia

*Corresponding author; email: rakhmat.fakhruddin@esdm.go.id

Received: 16 March 2020

Accepted: 19 November 2020 